УДК 37.018.43:004.78] : 005.953

Коневщинська Ольга Еммануїлівна

кандидат педагогічних наук, вчений секретар

Інститут інформаційних технологій і засобів навчання НАПН України, м. Київ, Україна

olgak1972@mail.ru

\title{
КАДРОВЕ ЗАБЕЗПЕЧЕННЯ РЕСУРСНОГО ЦЕНТРУ ДИСТАНЦІЙНОЇ ОСВІТИ
}

\begin{abstract}
Анотація. У статті проаналізовано основні категорії фахівців, які здійснюють організаційну, адміністративну, навчально-методичну, технічну, технологічну підтримку процесу дистанційного навчання. Зазначено, що серед основних завдань діяльності ресурсних центрів дистанційної освіти є забезпечення додаткових освітніх програм у галузі ІКТ і дистанційної освіти для робітників освітньої галузі, а також організаційне, методичне та технічне забезпечення впровадження і розвитку IКТ та дистанційної освіти за освітніми програмами. Визначено основні вимоги до кваліфікаційного рівня кадрового забезпечення. Охарактеризовано комплекс професійно значущих якостей викладачів-тьюторів необхідних для успішної професійної діяльності. Виокремлено складові професійної компетентності мережних викладачів відповідно до структури діяльності.
\end{abstract}

Ключові слова: дистанційна освіта; кадрове забезпечення; ресурсний центр дистанційної освіти; професійна компетентність; професійні якості.

\section{1. ВСТУП}

Постановка проблеми. Необхідною умовою для визначення рівня підготовленості освітніх установ до впровадження дистанційної форми навчання, зокрема підключення до ресурсних центрів дистанційної освіти є аналіз саме процесу дистанційного навчання у загальноосвітніх навчальних закладах. Нині в Україні навчання за дистанційною формою здійснюється фрагментарно у вигляді окремих дистанційних курсів, опанування яких не забезпечує завершеного навчання учнів певного предмета.

Провідними вітчизняними науковцями (Биковим В., Богачковим Ю., Кухаренко В., та ін.) підготовлено проекти та робочі матеріали щодо розробки положень про дистанційне навчання в системі загальної середньої освіти, про ресурсний центр дистанційної освіти системи загальної середньої освіти, де вказуються основні вимоги щодо використання технологій дистанційного навчання, функцій основних підрозділів ресурсних центрів дистанційної освіти тощо, що слугує вагомим чинником у визначенні складу ІКТ-компетентностей учасників дистанційного навчання: учнів, учителів та керівників загальноосвітніх навчальних закладів $[6,7,8]$.

Важливим завданням дистанційного навчання для загальноосвітніх навчальних закладів є надання учням можливості отримати основні або додаткові якісні знання, набути вміння та навички відповідно до основної або додатково обраної навчальної програми (плану) за місцем їх проживання або тимчасового перебування дистанційно, без обов’ язкових очних контактів з учителем та перебування у навчальному закладі [6].

Питання кадрового забезпечення дистанційного навчального процесу завжди були в центрі уваги освітньої установи будь-якого рівня акредитації, які тільки планують надавати дистанційні освітні послуги або вже використовують технології дистанційного навчання. Кадрове забезпечення дистанційного навчання реалізується постійно діючою системою підготовки (підвищення кваліфікації) таких категорій фахівців дистанційного навчання: 
- педагогічних та науково-педагогічних працівників навчальних закладів;

- фахівців 3 інформаційних технологій - програмістів, адміністраторів мережевого навчання;

- менеджерів дистанційного навчання;

- методистів дистанційного навчання;

- експертів навчальних матеріалів для дистанційної освіти.

У нещодавно затвердженому наказі МОН України № 1518 від 30.10.2013р. «Про затвердження Вимог до вищих навчальних закладів та закладів післядипломної освіти, наукових, освітньо-наукових установ, що налають освітні послуги за дистанційною формою навчання з підготовки та підвищення кваліфікації фахівців за акредитованими напрямами i спеціальностями» окреслено мінімальні вимоги до організаційного, кадрового, науково-методичного, матеріально-технічного, програмного та інформаційного забезпечення закладів освіти, необхідні для надання освітніх послуг за дистанційною формою навчання. У цьому нормативно-правовому документі визначено відповідні показники вимог до забезпечення закладів освіти щодо надання освітніх послуг за дистанційною формою навчання 3 підготовки фахівців усіх освітньокваліфікаційних рівнів вищої освіти за акредитованими напрямами підготовки., серед яких є вимоги до кадрового забезпечення:

- $100 \%$ забезпеченість закладу освіти педагогічними, науково-педагогічними працівниками, методистами, які підвищували кваліфікацію з питань організації та використання технологій дистанційного навчання не менше одного разу за останні п'ять років і мають відповідний документ про підвищення кваліфікації;

- забезпеченість закладу освіти III-IV рівнів акредитації науково-педагогічними працівниками із науковими ступенями (вченими званнями), які розробляють дидактичне наповнення, педагогічні сценарії та метод рекомендації до вебресурсів/дистанційних курсів навчальних дисциплін (для підготовки бакалаврів - 40\%, спеціалістів/магістрів - 70\%); забезпечують навчальний процес за дистанційною формою навчання (для підготовки бакалаврів - 40\%, спеціалістів/магістрів - 50\%);

- забезпеченість закладу освіти I-II рівнів акредитації педагогічними працівниками вищої категорії, які: розробляють дидактичне наповнення, педагогічні сценарії та метод рекомендації до веб-ресурсів/дистанційних курсів навчальних дисциплін (для підготовки молодших спеціалістів - 15\%); забезпечують навчальний процес за дистанційною формою навчання (для підготовки молодших спеціалістів - 10\%) [10].

Аналіз останніх досліджень i публікацій. Розвиток дистанційної освіти в Україні пов'язаний з іменами таких учених як Биков В., Богачков Ю., Гриценко В., Жалдак М., Згуровський М., Кухаренко В., Лапінський В., Манако А., Морзе Н., Олійник В., Пінчук О., Стефаненко П., Щенніков С та ін. Проблеми реалізації компетентнісного підходу в процесі професійної підготовки вчителя, конкретизації змісту його професійних компетентностей досліджували В. Котенко, Л. Пєтухова, С. Раков, О. Спірін, О. Овчарук та ін.

Проблеми впровадження дистанційного навчання досліджено $\mathrm{y}$ роботах закордонних учених, серед яких Бергер Р., Беккер Х., Бленк Б., Бриттел Д., Деллінг Р., Рамблє Г., Каган Д., Сімонсон М., Мур М., Кларк А., Томпсон М., Хассон Дж та інші. Серед російських вчених питання дистанційної освіти досліджували Андрєєва А., Бухаркіна М., Моїсеєва М., Петров А., Полат Є., Хуторський А., Тихомирова О. та ін.

Проте, вивчення наукових джерел дозволяє стверджувати, що питання, пов'язані 3 підготовкою висококваліфікованого кадрового складу фахівців для ефективного 
впровадження технологій дистанційного навчання та функціонування ресурсних центрів дистанційної освіти на базі навчального закладу вивчено ще недостатньо.

Метою даної статті є розкриття сутності основних складових кваліфікаційних характеристик та вимог щодо кадрового забезпечення педагогічних i науковопедагогічних працівників навчальних закладів та ресурсних центрів дистанційної освіти. Дотримання окреслених вимог сприятиме правильному підбору і розстановці кадрів, підвищенню їхньої кваліфікації, раціональному розподілу праці, створенню дієвого механізму розмежування функцій, повноважень та відповідальності між працівниками, а також встановленню єдиних підходів у визначенні їхніх посадових і функціональних обов'язків, які дають можливість забезпечити ефективність процесу дистанційного навчання.

\section{2. МЕТОДИ ДОСЛІДЖЕННЯ}

Під час проведеного дослідження щодо вивчення питань кадрового забезпечення процесу дистанційного навчання та функціонування ресурсного центру дистанційної освіти було використано комплекс теоретичних та емпіричних методів, серед яких: системний та порівняльний аналіз психолого-педагогічної, навчально-методичної та науково-технічної літератури з проблем дослідження; узагальнення тощо.

\section{3. РЕЗУЛЬТАТИ ДОСЛІДЖЕННЯ}

У розробленому вітчизняними науковцями «Типовому положенні про ресурсний центр дистанційної освіти системи загальної середньої освіти» зазначено, що до обов'язкового нормативно-правового забезпечення впровадження дистанційного навчання у ресурсному центрі дистанційної освіти (РЦДО) відносяться документи щодо планування навчального процесу (навчальні програми, навчальні плани, навчально-тематичні плани, розклади занять) та визначення предметів (тем), видів навчальних занять і контрольних заходів, які здійснюються за дистанційною формою.

Ресурсний центр дистанційної освіти має можливість розробляти: власне Положення та затверджує його в $\mathrm{MOH}$ України. Додатково розробляються та затверджуються МОН (а у разі відсутності таких положень, самими РЦДО) наступні нормативні документи:

1. Положення про створення, оновлення, використання, захист і зберігання вебресурсів навчальної програми (дисципліни).

2. Положення про науково-методичну експертизу та сертифікацію веб-ресурсів навчальної програми (дисципліни).

3. Положення про затвердження норм часу для обліку методичної та навчальної роботи педагогічних працівників РЦДО при організації навчального процесу [9].

Серед багатьох завдань для організації роботи РЦДО є такі:

4. Організація інформаційної підтримки дистанційного навчання учнів, вчителів, керівників.

5. Формування фонду матеріалів РЦДО, у тому числі з альтернативних джерел.

6. Реклама ресурсного центру його можливостей у ЗМІ та серед освітянської громадськості.

7. Здійснення цілеспрямованого інформування педагогічної спільноти про роботу РЦДО. 
Зміст роботи створеного центру передбачає забезпечення інформаційного обслуговування користувачів тобто надання можливості вільного доступу до фондів РЦДО. Робота 3 фондами включає організацію інформаційно-пошукових систем; ведення обліку та забезпечення збереження фонду РЦДО; організацію виставкової роботи та реклами фонду РЦДО.

Координація та взаємодія 3 навчальним закладом або науковою установою забезпечується спільним визначенням завдань Ресурсного Центру Дистанційної Освіти і складанням планів (програм) роботи; наданням додаткових сервісних платних послуг.

Організація роботи та управління РЦДО здійснюється відповідно до державних установчих документів, зокрема, облік і звітність ведеться за встановленими формами; призначається відповідальний за роботу центру (керівник), обов'язки якого визначаються посадовою інструкцією.

При дослідженні ефективності роботи РЦДО слід звернути увагу на дві взаємопов'язані складові, а саме: функцію забезпечення дистанційного навчання iз застосуванням інформаційно-комунікаційних технологій та функцію практичного дистанційного моніторингу підготовленості учнів, вчителів та керівників до використання IКТ. Основною метою діяльності ресурсних центрів дистанційної освіти є забезпечення додаткових освітніх програм у галузі ІКТ і дистанційної освіти для робітників освітньої галузі, а також організаційне, методичне та технічне забезпечення впровадження і розвитку ІКТ та дистанційної освіти за освітніми програмами.

Для організації підключення навчального закладу до мережі РЦДО вважаємо за доцільним визначити необхідні організаційні заходи, серед яких:

1. Закупівля обладнання для Центрів (персональні комп'ютери, принтери, сканери, мультимедійні дошки тощо).

2. Створення локальних мереж в органах місцевого самоврядування та навчальних закладах районів для підключення Центрів 3 використанням існуючих каналів.

3. Визначення джерел, механізмів та процедур збору і актуалізації необхідної інформації для Центрів.

4. Створення баз даних для Центрів та розроблення форм представлення інформації у вигляді веб-сторінок.

5. Підготовка визначених працівників у загальноосвітніх навчальних закладах для обслуговування Центрів. Проведення навчань та семінарів.

6. Прийняття необхідних нормативних документів для впровадження Центрів та надання пілотних освітніх послуг у електронному вигляді.

Структура та функції основних підрозділів ресурсних центрів дистанційної освіти, які забезпечують дистанційне навчання за програмами середньої освіти:

- адміністративний підрозділ;

- підрозділ клієнтського обслуговування, що забезпечує укладання договорів із навчальними закладами та фізичними особами з надання послуг дистанційного навчання;

- підрозділ, що забезпечує організацію навчального процесу, формування змісту навчання та здійснює науково-методичне, кадрове забезпечення;

- підрозділ, що забезпечує організаційно-технологічну та інформаційнокомунікаційну підтримку дистанційного навчання;

- інші підрозділи, які беруть безпосередню участь у навчальному процесі, у розробленні та використанні веб-ресурсів, необхідних для реалізації дистанційного навчання [6]. 
Ресурсний центр дистанційної освіти забезпечує роботу необхідної кількості мережних викладачів і надає користувачам необхідні освітні ресурси/послуги в порядку і на умовах, визначених угодою сторін.

Співробітники центру можуть працювати у РЦДО як на постійній, так і на договірній основі.

Навчання за дистанційною формою забезпечують такі категорії фахівців РЦДО як:

- педагогічні працівники, які виконують функції викладачів, консультантів, педагогів-кураторів навчальних груп, авторів дидактичного і методичного наповнення веб-ресурсів (дистанційних курсів). Кваліфікаційні вимоги i посадові обов'язки мережних викладачів (тьюторів) і педагогів кураторів встановлюються Типовими посадовими інструкціями відповідно на мережного викладача та педагога куратора. Мережні викладачі і педагоги-куратори володіють всіма правами і соціальними гарантіями, передбаченими для педагогічних працівників загальноосвітніх установ.

Педагогічна робота мережних викладачів і педагогів-кураторів у системі дистанційного навчання визначається наявністю встановленого переліку видів навчальної і методичної роботи та відповідних норм часу для їх виконання. Виконання аудиторної роботи педагогами-кураторами і дистанційної роботи 3 учнями мережними викладачами регулюється розкладом навчальних занять. Виконання мережними викладачами і педагогами-кураторами позааудиторної роботи, що випливає 3 ïх посадових обов'язків, регулюється графіками i планами роботи, у тому числі, індивідуальними планами педагогічного працівника.

- методисти, які беруть участь в організації навчального процесу, взаємодії між викладачами (тьюторами) і учнями в синхронному і асинхронному режимах, надають методичну допомогу під час розроблення веб-ресурсів навчальної програми;

- адміністративно-керівний склад, який виконує функції керівників підрозділів і (або) керівників окремих напрямів i видів забезпечення дистанційного навчання;

- інженерно-технічний склад - фахівці 3 інформаційно-комунікаційних технологій, які виконують функції програмістів, веб-дизайнерів, системних адміністраторів тощо;

- допоміжний персонал [9].

Розглянемо детальніше функціональні обов'язки кожної категорії фахівців, задіяних у процесі дистанційного навчання.

Функціональні обов’язки педагогічних працівників РЦДО передбачають:

- розроблення документів планування навчального процесу;

- розроблення і своєчасне оновлення змістовного, дидактичного та методичного наповнення веб-ресурсів навчальної програми;

- реалізацію навчальних заходів, передбачених навчальною програмою, включаючи консультації, семінари, дискусії, рольові ігри, лекції тощо як у синхронному, так і асинхронному режимах з використанням графічного, аудіота відеоформатів;

- індивідуалізацію навчального процесу шляхом персональної адаптації педагогічного сценарію та підвищення мотивації учня;

- проведення контрольних заходів;

- консультування учнів під час навчання та підготовки випускних робіт; 
- надання аналітичних звітів щодо результатів виконання учнями навчальних програм керівнику ЗНЗ.

Функціональні обов'язки адміністративно-управлінського персоналу РЦДО передбачають:

- координування дій всіх структурних підрозділів РЦДО щодо якісного, своєчасного надання навчальних послуг за програмами середньої освіти за дистанційною формою;

- моніторинг якості організації навчального процесу за дистанційною формою та результатів навчання учнів;

- контроль за рівнем нормативно-правового, організаційного, науковометодичного, кадрового, системотехнічного та фінансового забезпечення дистанційного навчання у РЦДО;

- організацію сертифікації та науково-методичної експертизи веб-ресурсів кожної навчальної програми (дисципліни);

- участь у національних і міжнародних проектах, націлених на розширення можливостей доступу різних категорій фахівців до якісного навчання за програмами середньої освіти;

- контроль за надходженням і цільовим використанням коштів.

Функціональні обов'язки інженерно-технічного персоналу РЦДО передбачають:

- безперебійне функціонування апаратних засобів, телекомунікаційного i програмного забезпечення;

- розроблення і оновлення веб-ресурсів, у тому числі і програмне забезпечення спеціального призначення;

- розроблення додаткових елементів програмного забезпечення, необхідних для реалізації дистанційного навчання;

- підтримку високої якості інформаційно-комунікаційної складової веб-ресурсів навчальних програм, цілодобовий доступ до всіх веб-ресурсів та відповідних веб-сервісів;

- своєчасне надання доступу учасникам навчального процесу до веб-сервісів, що забезпечують проведення навчальних занять у синхронному режимі;

- консультування учнів і науково-педагогічних (педагогічних) працівників щодо технологічних аспектів їх участі в навчальних заходах у синхронному та асинхронному режимах;

- консультування всіх учасників навчального процесу щодо використання автоматизованої системи управління навчальним процесом;

- заходи щодо надійного захисту і збереження всіх інформаційних ресурсів, які містяться на серверах РЦДО;

- інші заходи, яких вимагає постійна технологічна підтримка дистанційного навчання.

Функціональні обов'язки допоміжного персоналу РЦДО передбачають:

- ведення документації, необхідної для нормативно-правового та організаційного забезпечення дистанційного навчання в РЦДО;

- необхідну взаємодію між учнями та науково-педагогічними (педагогічними) працівниками;

- ведення бази даних учнів та науково-педагогічних (педагогічних) працівників;

- ведення листування 3 учнями та надання їм необхідної документації, організаційної допомоги;

- контролювання участі учнів у навчальному процесі; 
- участь у наборі учнів, проведенні маркетингових досліджень та рекламних заходів [6].

Отже, вищезазначене дає підстави вважати, що для забезпечення дистанційного навчання визначені функціональні обов'язки окреслюють певні вимоги щодо рівня професійної, інформаційної, інформаційно-комунікативної, інноваційної та правової компетентностей учителів та керівників загальноосвітніх навчальних закладів та РЦДО.

Також у чинному наказі МОН України «Про затвердження кваліфікаційних характеристик професій (посад) педагогічних та науково-педагогічних працівників навчальних закладів»[5] зазначено, що 3 метою удосконалення організації та підвищення ефективності праці працівників загальноосвітніх навчальних закладів та установ освіти, можливе розширення кола їх обов'язків у порівнянні з обов'язками, що визначені відповідними кваліфікаційними характеристиками. У цих випадках без зміни назви посади працівнику за його згодою може бути доручено виконання обов'язків, що передбачені кваліфікаційними характеристиками інших посад, які близькі за змістом робіт, аналогічними за складністю, виконання яких не вимагає іншої спеціальності, кваліфікації та діяльність яких безпосередньо пов'язана 3 навчальним i науковопедагогічним процесом.

Кваліфікаційні характеристики застосовуються як нормативні документи і можуть служити основою для розробки посадових інструкцій, що містять конкретний перелік посадових обов'язків працівників з урахуванням особливостей організації праці та управління, їх прав, відповідальності та компетентності. При необхідності посадові обов'язки, що зазначені у кваліфікаційній характеристиці працівника, можуть бути розподілені між кількома виконавцями.

Кваліфікаційна характеристика кожної посади має три розділи: «Завдання та обов'язки», «Повинен знати» $\mathrm{i}$ «Кваліфікаційні вимоги».

У розділі "Завдання та обов'язки" міститься перелік основних трудових функцій, що можуть бути повністю або частково доручені працівникові, який займає певну посаду 3 урахуванням технологічної однорідності та взаємозв'язку робіт, що дозволяють забезпечити оптимальну спеціалізацію за посадами керівника, професіонала та фахівця.

У розділі "Повинен знати" містяться основні вимоги, що висуваються до працівника щодо професійних знань, а також знань законодавчих та інших нормативних правових актів, положень, інструкцій та інших документів, методів і засобів, які працівник повинен застосовувати при виконанні посадових обов'язків.

У розділі "Кваліфікаційні вимоги" визначено необхідний для виконання посадових обов'язків рівень професійної підготовки працівника, що засвідчується документами про освіту, а також вимоги до стажу роботи.

Особи, які не мають відповідної освіти або стажу роботи, встановлених кваліфікаційними вимогами, але мають достатній практичний досвід та успішно виконують у повному обсязі покладені на них завдання та обов'язки, можуть бути, як виняток, залишені на займаній посаді або призначені на відповідні посади за рекомендацією атестаційної комісії.

Крім цього, у кваліфікаційній характеристиці посади педагогічного, науковопедагогічного працівника мають бути відображені його компетентності. При цьому під компетентністю розуміється якість дій працівника, що забезпечують адекватне та ефективне вирішення професійно важливих предметних завдань дистанційного навчання , що мають проблемний характер, а також готовність нести відповідальність за свої дії. До важливих компетентностей педагогічних працівників дистанційної освіти відносять: професійну, інформаційну, інформаційно-комунікативну, інноваційну, правову. 
Розглянемо деякі компетентності які характеризують відповідні вміння та навички педагогічних i науково-педагогічних працівників, зокрема тих, що забезпечують процес дистанційного навчання.

Професійна компетентність - якість дії працівника, що забезпечує ефективність вирішення професійно-педагогічних проблем і типових професійних завдань, які виникають у реальних ситуаціях педагогічної чи науково-педагогічної діяльності, і залежить від кваліфікації, загальноприйнятих цінностей моралі та етики, володіння освітніми технологіями, технологіями педагогічної діагностики (опитування, індивідуальні та групові інтерв'ю) та психолого-педагогічної корекції, життєвого досвіду, постійного удосконалення та впровадження у практику ідей сучасної педагогіки, методів навчання та викладання навчальних дисциплін i предметів, використання наукової літератури та інших джерел інформації для створення сучасних форм навчання, впровадження оціночно-ціннісної рефлексії.

Інформаційна компетентність - якість дій працівника, що забезпечують ефективний пошук, структурування інформації, ऑiі адаптацію до особливостей педагогічного процесу i дидактичних вимог, формулювання навчальної проблеми різними інформаційно-комунікативними способами, кваліфіковану роботу з різними інформаційними ресурсами, професійними інструментами, готовими програмнометодичними комплексами, що дозволяють проектувати рішення педагогічних проблем і практичних завдань, використання автоматизованих робочих місць педагогічного та науково-педагогічного працівника в освітньому процесі; регулярну самостійну пізнавальну діяльність, готовність до ведення дистанційної освітньої діяльності, використання комп'ютерних і мультимедійних технологій, цифрових освітніх ресурсів в освітньому процесі, ведення документації навчального закладу на електронних носіях.

Інформаційно-комунікативна компетентність - якість дії працівника, що забезпечує ефективний прямий та зворотній зв’ язок з особою, яка навчається, контакт 3 учнями (вихованцями, дітьми) різного віку, студентами, батьками (особами, які їх заміняють), колегами, здатність до розробки стратегії, тактики і техніки взаємодії $з$ людьми, організацію їхньої спільної діяльності для досягнення певних суспільно значимих цілей; здатність переконувати, стверджувати свою позицію; володіння державною мовою, грамотним усним та писемним діловим мовленням, ораторським мистецтвом, професійним етикетом, а також навичками публічної презентації результатів роботи, вміннями обирати відповідні форми і методи презентації.

Дистанційне навчання, на думку В. Кухаренка, Е. Полат та ін., визначено як різновид відкритого навчання з використанням комп'ютерних та телекомунікаційних засобів, що забезпечують інтерактивну взаємодію викладачів/учителів та студентів/учнів на різних етапах навчання і самостійну роботу останніх із матеріалами інформаційної мережі, більшість з яких підготовлена викладачами [3].

У сучасному ДН спектр функцій, які виконує викладач, якого називають тьютором, змінюється: деякі відомі функції (які притаманні і традиційним формам навчання) стають домінуючими (наприклад, координація навчально-пізнавального процесу, коригувального курсу, який викладається, керівництво навчальними проектами, перевірка поточних завдань, тощо), а деякі - виникають як нові (наприклад, консультування при складанні індивідуального навчального плану, управління навчальними групами взаємопідтримки, допомога учня або студентам у їх професійному самовизначенні, фільтрації мережних електронних джерел навчальної інформації, підготовка віртуальних навчальних ситуаційних завдань тощо). Перед педагогічним персоналом і організаторами дистанційної освіти ставиться завдання 
навчити суб' єкта навчання вчитися, сформувати у нього методологічний фундамент і сучасні технологічні прийоми навчання впродовж усього життя [1].

Розглянемо функції та нову роль викладача (тьютора) в системі дистанційного навчання.

Тьютор (викладач-консультант) організовує ефективне вивчення курсу, проводить семінари і консультує студентів, перевіряє і коментує письмові завдання. Специфіка дистанційного навчання (стислість занять, їх інтенсивний характер, робота 3 дорослими) висуває до викладача-тьютора вимоги, які істотно відрізняються від традиційних, як за особистісними якостями, так і методиками навчання.

Тьютор створює освітнє середовище, що дозволяє студентові одержати знання та навички, вирішувати реальні проблеми у своїй діяльності. При цьому тьютор допомагає максимально ефективно використовувати різноманітні навчальні матеріали, Інтернет, практичний досвід інших студентів. Безсумнівно, викладач у системі дистанційного навчання повинен володіти Інтернет-технологіями, технологією електронної пошти, комп'ютерними навчальними програмами, чат-технологією, Web-технологіями.

Безперервний розвиток тьюторів забезпечується за рахунок формування професійного тьюторського середовища. Тьютор має можливість взаємодіяти 3 колегами, беручи участь у постійно діючих Інтернет-конференціях, виїзних школах тьюторів, різних семінарах, авторських семінарах, конференціях. Використовуючи ці різноманітні форми взаємодії, обмінюються досвідом, дізнаються про нові компоненти курсів, створюють спільне бачення підходів до проведення занять та оцінювання. Тьюторіал у дистанційному навчанні - це очне заняття, проведене тьютором на основі активних методів навчання і спрямоване як на засвоєння студентами певного матеріалу, так і на контроль знань, умінь і навичок студентів. Тому викладач повинен володіти сучасними педагогічними та комп'ютерними технологіями.

Як зазначає В. Кухаренко, стратегія системи підвищення кваліфікації викладачів повинна бути спрямована на створення цілісної та гнучкої моделі навчання, яка включатиме як звичайну, так і дистанційну форми навчання, й базується на таких засадах: дистанційні матеріали повинні враховувати потреби навчання та специфіку майбутньої аудиторії; легко пристосовуватися до індивідуальних потреб слухача; бути добре структурованими на окремі навчальні одиниці 3 окресленими навчальними цілями на початку, вступом, основною частиною, навчальними вправами, вправами для самооцінки знань, проміжними тестами, елементами зворотного зв'язку та підсумовуванням здобутих знань; простими для використання в якості елементів самопідготовки 3 чіткими навігаційними інструкціями; інтерактивними орієнтованими на вивчення через здійснення практичних дій та поточну самооцінку знань із використанням результатів оцінювання для надання зворотного зв'язку; прив’ язаними до контексту інших існуючих навчальних джерел, які висвітлюють дану проблему з різних позицій; такими, що сприяють розвитку навичок спілкування в дистанційному режимі, як по лінії слухач-викладач, так і по лінії слухач-слухач; такими, що стимулюють мотивацію та ініціативу слухача; орієнтованими на досягнення як загальних, так і конкретних навчальних цілей, окреслених перед початком кожного розділу та розвиток навичок самостійного навчання [3].

Тьютори поєднують у собі якості:

- викладача - проводять тьюторські заняття; допомагають студентам у навчанні; забезпечують правильну організацію та контроль самостійної роботи, ефективне використання навчально-методичної літератури тощо;

- консультанта — координують пізнавальний процес студентів; проводять групові та індивідуальні консультації, комунікативні заняття тощо; 
- менеджера - організовують процес навчання за індивідуальним графіком, управляють проведенням групових тьюторських занять; контролюють виконання студентами контрольних заходів (вхідний, поточний та підсумковий контроль).

Тьютори мають пройти попередню психолого-педагогічну підготовку. Виконувати функції тьютора можуть досвідчені викладачі з високими професійними, організаторськими, комунікативними, управлінськими та іншими якостями.

До професійних обов'язків тьютора входить:

- створення сприятливих умов для організації та контролю самостійної роботи студентів;

- проведення індивідуальних та групових консультацій студентів;

- надання науково-методичної допомоги студентам у процесі навчання;

- забезпечення правильного та ефективного використання навчально-методичної літератури;

- координування самостійної навчальної діяльності студентів під час позааудиторної самостійної роботи;

- перевірка самостійних письмових домашніх завдань [2].

Тьютор виконує функції керівника, координатора, консультанта. До нього звертаються як до авторитетного джерела інформації, як до експерта. Змінюються форми співробітництва викладачів і студентів. Обговорення поточних результатів у групі, дискусії, «мізкові атаки», доповіді, виступи набувають дещо іншого характеру.

Тому до тьютора висуваються високі професійні та ділові вимоги: він має володіти не лише вміннями наукової, педагогічної, методичної діяльності, йому повинні бути притаманні комунікативні, організаторські, менеджерські вміння та якості.

Тьютор не викладає матеріал (він є в підручниках, посібниках), а дає пояснення, консультації щодо кращого опанування матеріалом, організовує та координує, перевіряє самостійну роботу, виконання домашніх письмових завдань.

Підготовка тьюторіалів — це одне 3 найважливіших завдань тьютора. Кожен тьютор має досвід викладання, знання, враховує вимоги до планування, організації і контролю СРС тощо.

Крім того він зважає на рівень підготовки студентів, має індивідуальний підхід до кожного з них.

При проведенні тьюторіалів «повчальне» спілкування неможливе, оскільки всі студенти - особистості, які заслуговують на повагу.

На тьюторіалах у межах модульної технології завданням тьютора $\epsilon$ діагностування та оцінювання виконання домашніх самостійних письмових робіт, при цьому обов'язковим $є$ коментування виконаних завдань, унесення корективів у процес навчання.

Тьютор не може примусити студента самостійно навчатися, але він створює максимально сприятливі умови для організації його самостійного навчання, посилює мотивацію якісного й сумлінного виконання завдань.

За результатами досліджень вітчизняних учених, у системі дистанційного навчання від викладача вимагається низка спеціальних умінь, зокрема:

- мати широкий кругозір щодо питань застосування інформаційних та комунікаційних технологій в освіті;

- володіти комп'ютерною грамотою на рівні кваліфікованого користувача;

- уміти працювати з локальною та корпоративною мережею (Інтранет/Інтернет) у межах доступу до своєї категорії користувача; 
- мати чітке уявлення про технології, методики та форми організації дистанційного навчання;

- уміти проектувати та створювати електронні цифрові ресурси;

- володіти навичками інтерактивних форм взаємодії зі студентами;

- знати та застосовувати форми контролю знань, умінь та навичок в умовах Інтернет-освіти;

- вести електронну документацію;

- знати та враховувати в роботі педагогічні та психологічні основи дистанційного навчання [4].

Отже, узагальнюючи вищевикладений матеріал нашого дослідження вважаємо за доцільним визначити основні характеристики діяльності мережного викладача, а саме:

- мережний викладач допомагає прояву активності у віртуальному середовищі і повсякчасно мотивує навчальну діяльність;

- працює індивідуально, дає поради або консультації щодо допомоги отримати задоволення від вивчення курсу;

- визначає через зворотний зв'язок доцільність i правильність навчальної діяльності студента/учня;

- визначає необхідність залучення до процесу нових знань, що відповідають змісту навчання і здатні підвищити його якість;

- визначає напрямок зростання студента/учня у розумінні змісту курсу;

- визначає стратегію і якість виконання або необхідну допомогу у виконанні технологічного вибору, що покращують умови навчального простору студента/учня;

- визначає задачі проектування як у курсі, так і у просторі курсу, на які доречно звернути увагу, та конструює додаткові засоби діяльності, які мають удосконалити проведення курсу;

- визначає проблеми реєстрації студента/учня, збереження записів та ін.

\section{4. ВИСНОВКИ ТА ПЕРСПЕКТИВИ ПОДАЛЬШИХ ДОСЛІДЖЕНЬ}

Таким чином, на підставі вищезазначеного можна дійти певних висновків.

Головною метою створення мережі РЦДО є забезпечення загальнонаціонального доступу до електронних освітніх ресурсів шляхом використання сучасних інформаційних технологій та телекомунікаційних мереж і надання умов для реалізації громадянами своїх прав на освіту.

Соціальне значення РЦДО полягає у можливості позитивного впливу на вирішення таких проблем як:

- підвищення рівня ІКТ освіченості суспільства і якості дистанційної освіти;

- реалізація потреб населення в освітніх послугах на дистанційній основі;

- підвищення соціальної і професійної мобільності населення;

- збереження та поновлення знань, кадрового i матеріально-технічного потенціалу, що накопичені вітчизняною системою освіти;

- формування єдиного інформаційно-освітнього простору в педагогічній галузі.

Рівень знань та умінь фахівців, задіяних у дистанційному навчанні, повинен відповідати стандартам кадрового забезпечення дистанційного навчання або тимчасовим вимогам до нього. Обов' язковою вимогою має бути наявність відповідних атестаційних документів (сертифікатів), що підтверджують достатність їхнього рівня знань і умінь для якісного забезпечення ними технологій дистанційного навчання.

Механізм створення та функціонування постійно діючої системи підготовки або підвищення кваліфікації фахівців дистанційного навчання, а також методичне 
забезпечення цієї підготовки має бути об'єктом для вивчення науково-методичними комісіями відповідних контролюючих установ на державному рівні. Необхідно створити перелік центрів, на базі яких проводиться підготовка/перепідготовка педагогічних, науково-педагогічних працівників, які виконують функції викладачів, консультантів, кураторів навчальних груп, авторів дидактичного та методичного наповнення навчально-методичних комплексів; тьюторів, які беруть участь в організації навчального процесу, під час взаємодії між викладачами та слухачами у синхронному та асинхронному режимах; працівників центру дистанційного навчання, які здійснюють організаційну, адміністративну, навчально-методичну, технічну, технологічну підтримку процесу дистанційного навчання.

Перспективи подальших досліджень спрямовані на вивчення питань щодо визначення рівнів ІКТ-компетентностей фахівців, залучених до процесу дистанційної освіти.

\section{СПИСОК ВИКОРИСТАНИХ ДЖЕРЕЛ}

1. Биков В. Ю. Сучасні завдання інформатизації освіти / В. Ю. Биков. // Інформаційні технології і засоби навчання: електронне наукове фахове видання [Електронний ресурс] / Ін-т інформ. технологій і засобів навчання АПН України, Ун-т менеджменту освіти АПН України; гол. ред.: В.Ю. Биков. - 2010. - № 1(15). - Режим доступу: http://www.ime.edu-ua.net/em15/emg.html

2. Дерба Т.О. Функціональні обов'язки тьютора мереженого дистанційного навчання школярів / Т.О.Дерба // Інформаційні технології і засоби навчання: електронне наукове фахове видання [Електронний ресурс] 2010. - № 5(19). - Режим доступу до журналу: http://www.ime.eduua.net/em.html

3. Биков В. Ю., Кухаренко В. М., Сиротенко Н. Г., Рибалко О. В., Богачков Ю. М. Технологія розробки дистанційного курсу. Навчальний посібник. - К.: Міленіум, 2008. - 323 с.

4. Жевакіна Н. В. Професійні функції діяльності викладача-тьютора в умовах дистанційного навчання / Н. В. Жевакіна, М. А. Семенов // Вісник ЛНУ імені Тараса Шевченка. - 2011. - №5 (216). - C. 5-9.

5. «Про затвердження кваліфікаційних характеристик професій (посад) педагогічних та науковопедагогічних працівників навчальних закладів». Наказ $\mathrm{MOH}$ № 665 від 01.06.13 року [Електронний ресурс] Режим доступу: http://osvita.ua/legislation/other/37302/list/2/

6. Основи стандартизації інформаційно-комунікаційних компетентностей в системі освіти України : метод. рекомендації /[В. Ю. Биков, О. В. Білоус, Ю. М. Богачков та ін.] ; за заг. ред. В. Ю. Бикова, О. М. Спіріна, О. В. Овчарук. - К. : Атіка, 2010. - 88 с.

7. Організація середовища дистанційного навчання в середніх загальноосвітніх навчальних закладах : посібник / [Богачков Ю.М., Биков В.Ю, Пінчук О.П., Манако А.Ф. та ін.] ; під наук. ред. Ю.М. Богачкова. - К.: Педагогічна думка, 2012. - 160 с.: іл.

8. Богачков Ю.М. Ключові питання створення Концепції мережі ресурсних центрів дистанційної освіти загальноосвітніх навчальних закладів / Ю. М. Богачков, О. П. Пінчук // Інформаційні технології і засоби навчання. - 2013. - № 3 (35). - С. 83-98. - Режим доступу : http://journal.iitta.gov.ua/index.php/itlt/article/view/854

9. Типове положення про ресурсний центр дистанційної освіти системи загальної середньої освіти. [Електронний ресурс]. Режим доступу : http://lib.iitta.gov.ua/id/eprint/406

10. «Про затвердження Вимог до вищих навчальних закладів та закладів післядипломної освіти, наукових, освітньо-наукових установ, що налають освітні послуги за дистанційною формою навчання 3 підготовки та підвищення кваліфікації фахівців за акредитованими напрямами $\mathrm{i}$ спеціальностями». Наказ МОН України № 1518 від 30.10.2013 p [Електронний ресурс]. Режим доступу : http://ipo.kpi.ua/fileadmin/template/Nakaz_Vimogi_30_10_13.pdf

Матеріал надійшов до редакиї 19.12.2013 p. 


\title{
КАДРОВОЕ ОБЕСПЕЧЕНИЕ РЕСУРСНОГО ЦЕНТРА ДИСТАНЦИОННОГО ОБРАЗОВАНИЯ
}

\author{
Коневщинская Ольга Эммануиловна \\ кандидат педагогических наук, ученый секретарь \\ Институт информационных технологий и средств обучения НАПН Украины, г. Киев, Украина \\ olgak1972@mail.ru
}

\begin{abstract}
Аннотация. В статье проанализированы основные категории специалистов, которые осуществляют организационную, административную, учебно-методическую, техническую, технологическую поддержку процесса дистанционного обучения. Отмечено, что среди основных заданий деятельности ресурсных центров дистанционного образования является обеспечение дополнительных образовательных программ в области ИКТ и дистанционного обучения для работников образования, а также организационное, методическое и техническое обеспечение внедрения и развития ИКТ и дистанционного обучения по образовательным программам. Определены основные требования к квалификационному уровню кадрового обеспечения. Охарактеризован комплекс профессионально значимых качеств преподавателей-тьюторов необходимых для успешной профессиональной деятельности. Выделены составляющие профессиональной компетентности сетевых преподавателей в соответствии со структурой деятельности.
\end{abstract}

Ключевые слова: дистанционное образование; кадровое обеспечение; ресурсный центр дистанционного образования; профессиональная компетентность; профессиональные качества.

\section{STAFF PROVISION OF DISTANCE EDUCATION RESOURCE CENTER}

\author{
Olga E. Konevchshynska \\ Ph.D (pedagogical sciences), academic secretary \\ Institute of Information Technologies and Learning Tools of NAPS of Ukraine, Kyiv, Ukraine \\ olgak1972@mail.ru
}

\begin{abstract}
The article analyzes the main categories of professionals who carry out the organizational, administrative, teaching, technical, technological support of distance learning. It is indicated that the main purpose of distance education resource centers is to provide additional educational programs in the field of ICT and distance education for workers of education industry as well as organizational, methodological and technical support for the implementation and development of ICT and distance learning for educational programs. The basic requirements for qualification of personnel support; the characteristic set of professionally significant qualities of teachers, tutors needed for a successful profession, as well as determined components of professional competence network of teachers according to the structure of activity are presented.
\end{abstract}

Keywords: distance education; staffing; distance education resource center; professional competence; professional skills.

\section{REFERENCES (TRANSLATED AND TRANSLITERATED)}

1. Bykov V. Y. Modern task information education / V. Bykov / Information technology and learning tools: electronic scientific specialized edition / Inst inform. technology and training Sciences of Ukraine, Univ of Management Education Pedagogical Sciences of Ukraine, Ch. eds.: V. Bykov. - 2010. - № 1 (15) ( in Ukrainian)

2. Derba TO Functional responsibilities tutor of network distance education students [online] / T.O.Derba // Information technology and learning tools: electronic scientific specialized edition [electronic resource] 2010. - № 5 (19). - Available from: http://www.ime.edu-ua.net/em.html (in Ukrainian)

3. Bykov V. Y, Kuharenko V. M, Sirotenko N. G Rybalko O. V Bohachkov Y. M. Technology development of distance learning course. Manual. - K.: Millennium, 2008. - 323 p. ( in Ukrainian) 
4. Zhevakina N. V. Professional business features teacher-tutor in terms of distance education / NV Zhevakina, M. A. Semenov / Bulletin LNU Taras Shevchenko. - 2011. - №5 (216). - p. 5-9. ( in Ukrainian)

5. On approval of job descriptions professions (positions) teaching and teaching staff of educational institutions. Order of the Science of Ukraine № 665 from 01.06.13 year [online]. - Available from: http://osvita.ua/legislation/other/37302/list/2/( in Ukrainian)

6. Fundamentals of standardization of information and communication competencies in the education system of Ukraine: method. recommendations / [V. Bykov, O. Bilous, Y. Bohachkov et all.], For the Society. eds. V .Bykov, O. Spirin, O. Ovcharuk. - K.: Atika, 2010. - 88 p. ( in Ukrainian)

7. Organization learning environment in secondary schools: a guide [Text] / [BohachkovYu.M., BykovV.Yu, Pinchuk O.P., Manako A.F. ta in.]. - K. :Pedahohichnadumka, 2012. - 160 s. (in Ukrainian)

8. Bohachkov $\mathrm{Yu}$. M The key issue of establishing a network of resource centers concept of distance education secondary schools [online] / M. Bohachkov, O. Pinchuk / / Information technology and learning tools. - 2013. - № 3 (35). - P. 83-98. - Available from:: http://journal.iitta.gov.ua/index.php/itlt/article/view/854( in Ukrainian)

9. The default position of the Center for Distance Education of the general secondary education. [online]. Available from: http://lib.iitta.gov.ua/id/eprint/406( in Ukrainian)

10. Requirements for higher education and post-graduate education, research, educational and scientific institutions Setting educational services for distance learning with training and professional development for accredited and specialties." Order of the Science of Ukraine № 1518 of 10.30 .2013 p [online]. Available from: http://ipo.kpi.ua/fileadmin/template/Nakaz_Vimogi_30_10_13.pdf( in Ukrainian) 